\title{
The Impact of Local Communities on the School Development - A Case Study Examining Expectations and Inclusion on a Systemic Level
}

\author{
Stefanie A. Hillen \\ University of Agder \\ Kristiansand, Norway
}

\begin{abstract}
This paper presents one specific case of our school development research project. It shed light on the issue of a local community and the structure of expectations, which may limit the school's development and students' development. Because this project takes place in Scandinavia one needs first to understand the schooling policy called "one school for all", which stresses inclusion. In addition, the phenomenon Langfeldt describes as "the quality of schools is created locally" will be explained, as well as the nature of expectations. The data collected is used to show the case's limiting behavior, the balancing expectation structure between the school and the local community. Based on the conceptual model, both the preliminary SD-models told as dynamic stories and a running SD-model representing the case reveal that kind of behavior. To show the potential for the school development we compare the survey and focus group results with those of other control schools. Analyzing all schools will presumably show different main drivers for balancing expectations. From earlier research and literature analysis we derived indicators and characteristics for inclusive schools with high shared expectations, and a collegial school culture that are prerequisites for a school to be able to develop its potential.
\end{abstract}

Keywords: school improvement; inclusion; community; systemic development.

\section{Introduction}

The Scandinavian school policy 'One school for all' and inclusion. In general, the Scandinavian approach to schooling is an inclusive one and its egalitarian approach is well rooted in Scandinavian society. This is mirrored by the educational policy entitled 'one school for all' (see White paper, no. 28,1998- 1999). Actually, the Norwegian education system offers almost no special needs schools. To make the "one school for all" policy work, schools need to support all children according to their individual dispositions during schooling. All students, special education needs- children (SEN) as well as 
mainstream children, have the right to be taught adaptively in one classroom. This is laid down in the national core curriculum. This policy interpreted as an overall teaching strategy is called tilpasset opplxring (TPO) or adaptive teaching (Dale, 2008). In severe special- needs cases, extra support can be given to the student by a support team at the school, supporting students both in and out of the classroom, allowing them to be better included at school, socially as well as cognitively.

The focus on learning outcomes has influenced the schools in Norway too, specifically since national testing was introduced. A new national curriculum called kunnskapsløft (LK06) or 'knowledge promotion 2006' has stressed this too. The publication of the PISA- test results has also had an impact. In Norwegian schools one tendency can be observed: a higher ratio of students from 1st-10th grade (comprehensive school) receive extra support or are taken out for extra teaching hours, presumably to avoid a decrease in the average score, for instance as measured by national tests. This is a paradox, given the Norwegian inclusion approach and the stated educational policy as 'one school for all'. In addition, teachers' perceptions and expectations towards diagnosed SEN- children have become (unconsciously) internalized. Teachers appear to be making increasing use of the support teams. In consequence, an increasing ratio of 'problem kids' are sometimes sent out of the classroom and into the care of the support team.

\section{Quality in school is created locally}

The importance of the 'locality'. Because of the importance of the concept of the 'locality' which can influence the schools' quality and school development, as Langfeldt mentioned, one needs to understand what is meant by a school's local community or local context. In line with Langfeldt's description (2015, p.15) I propose to partially translate and redefine it as an aggregated scope of actions - cocreated and experienced by parents, teachers, the school and the community itselfwhich shape the youngsters' area for their opportunities and development. This paper will present the balancing effect of expectation structures adjusted over time by the local community and the school culture and vice versa. The phenomenon of the context, for instance external environment and situated context is discussed too in various publications (Pritchard, Morrow \& Marshall, 2007; Brau, Ball, Maguire \& Hopkins, 2011; Rist, 2007). A Swedish study takes a critical look at the concept of inclusion in the special education research field. The authors criticize the shortcomings induced by the too narrow use and understanding of the concept. Most of the definitions simply focus on the individual pupil's placement that is to accomplish inclusion by placing SEN-students in general education (level A), accommodating SEN and mainstream-students for their social and academic needs (level B and C), but they forget that the community (level D), as the highest category for inclusion, plays a key role in inclusion too. (Nilholm \& Göransson, 2013, Göransson \& Nilholm \& 2014).

Expectation and expectation structures. One driver for human behavior, attitudes, and decision making are expectations. They are important particularly in a learning context. One knows that low expectations can limit students' 
development if one thinks about the Rosenthal effect (Rosenthal \& Jacobson, 1992) or the so-called self- fulling prophecy with regard to problem children (Pritchard, Morrow \& Marshall, 2007). Even more important is the fact that students are well aware of what is expected by them.

"Research shows that, from a young age, students are able to identify teachers who have high and low expectations from observing their teacher's behavior. ... . These differences were argued to be picked up from the teachers' nonverbal behaviors ...". (Peterson, Rubie- Davies, Osborne \& Sibley, 2016, p. 124).

But expectations are not just built upon individuals, they are also created by organizations, institutions and between them. An empirical study on rural Norwegian schools showed a strong relationship between the parents' expectations of a given school, the parents' satisfaction and the school's reputation (Skallerud, 2011).

Collaboration, school culture and context. Even if collaboration sounds necessary for school development one need to consider what type of collaboration is in use. Hargreaves makes a distinction between collegial types of school cultures and collaboration in general.

"Collaboration does not necessarily involve an institutional base to its structure, but refers to a disposition towards, or the enactment of, a style of relationship which may take place in a very wide range of structural conditions." (Hargreaves, 1995a, p.31).

He further argues that collegiality is far from being a synonym for collaboration. An institutional structure is needed for collegiality-the collegium, or an organised society of persons performing certain common functions. (Hargreaves, 1995a).

"The collegial school type, with its stronger development structure and collaborative relationships that sustain teachers under stress, may be better placed to handle rapid change. ... . Collaboration conducted for its own sake, without regard to context or purpose, makes a dangerous educational principle (Hargreaves, 1995a, pp.40-42).

Finally, he concludes that collaboration is superficial if it lacks purpose and direction, which is wasteful and pointless (Hargreaves, 1995b).

As early as 1993, McLaughlin and Talbert (1993) mentioned the importance of the context and collaboration which affect the patterns of teachers' work. As a positive example they referred to teachers in a California School, which formed a strong school- wide community devoted to the success of all students in the school and to supporting one another's efforts to adapt instruction to meet students' learning needs. Teachers felt supported by their colleagues to succeed in their teaching and experienced professional growth in their daily working lives (McLaughlin \& Talbert, 1993). As mentioned before, the local community needs to be in focus as well (Shah, 2012). The study by Skallerud (2011), referred 
to above, showed that when a school meets the expectations of parents, the parents' loyalty increases sustainably, which then contributes to the good reputation of the school. The next chapter will address the systemic perspective in the project.

\section{The systemic perspective of School development - a first conceptual model on 'change of expectations'}

To visualize the systemic relationships, one needs to consider for school development, we make of use of System Dynamics- modelling. System Dynamics or System Thinking is seen as method, an approach, a philosophy or a thinking tool to solve complex problems (see Sterman, 2000).

The first step is a conceptual model. Our expectations with the modeling are:

- to visualize the project's idea (inside innovation),

- to reveal contradictions in the theories used as framework, and

- to be able reflect all the factors (variables) we have been using in our questionnaire and the other qualitative data collection instruments.

We refer as well to one underlying theory: the theory of change by Ivor Goodson. He stresses that, "Without a fully conceptualized notion of how the internal, external and personal will interlink, existing change theory remains underdeveloped and of progressively less use" (Goodson, 2001, p. 45). Therefore, this paper makes use of System Thinking (Senge, 1990) and System Dynamics (Sterman, 2000) as tools with which to identify and visualize the interlinkage of the central variables and the distinct kinds of behaviors respectively.

This paper explores a change of expectations understood as an ongoing process based on how local schools perceive their external expectations of as well as towards their local community. The assumption is that this process influences internal expectations for teachers and students and the school culture itself. In short, over time a balance will be reached-mutually-when it comes to the expectation structure in and about the school as well as towards the local community. As Hargreaves (2014) concludes that change originates itself within the school and not from a top- down process, there is a primary need to induce teachers to rethink and become conscious of their expectations.

The opportunity to rearrange the school structures of expectations and implicit role models for the students for an inclusive school will give teachers better working conditions for teaching and learning.

A working System Dynamics model (Sterman, 2000) is derived from underlying theory and on the first empirical data. The data already collected in this study (Project Description, 2016) has been applied to make the model and its premises more comprehensive and transparent (see Figure 5). Before starting the modeling process, a conceptual model was created (Figure 1).

The identified archetype, a balancing loop, which underlies the conceptual model, named 'balancing- expectations,' shows how a system stabilizes after a period of time to a level that is framed by the systems variables and parameters. This leads to a sustainable balancing process on a specific level. This kind of stabilization of the system is not necessarily negative, sometimes even desired. 


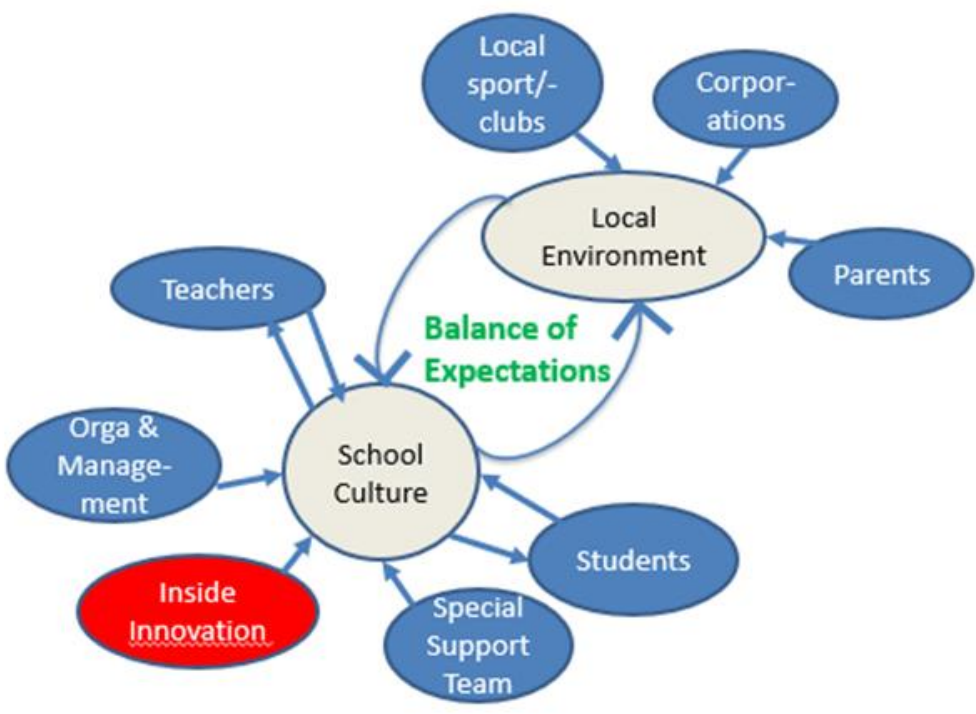

Figure 1: Conceptual model - a balancing loop on the structure of expectations

Compared with the investment of students in learning where the parameters are the time budget and the cognitive resources, the students' learning activities stop if the goal of a certain learning result is reached. This behavior is congruent with the structure of expectations created by a school culture and the local environment and vice versa.

From the project's point of view 'expectations' are seen as socially constructed by the school culture and by the local environment. To summarize, the so called reached and stabilized expectations can be redefined. The intention is to disturb that balancing behavior by reflecting activities with teachers by confronting them with their own expectations. The idea used is the so- called double loop learning approach (Senge, 1990). That means not to work on the symptoms or outcomes (e.g. school results) but on the causes shaping these expectations. Using the language of system thinking it means to change the mental models of the school culture's expectations.

Challenges and limitations using the modeling approach. Limitations can be seen in the chosen system boundary as well as in the underlaying theories used as a conceptual framework. The challenging, critical question of the systemboundary is: What variables are important and crucial to be included regarding a systemic inclusive school to enable and to foster school development? Hence, the selected variables can restrict the modeling and simulation results, which create the platform for the research results. However, to guarantee a comprised and appropriate research framework, we create and make use of models which take those variables into account which are described and revealed, deductive and inductive, by our quantitative and qualitative data collection tools (pre/postsurvey, focus group interviews, mapping techniques, world café and reflection circle).

Moreover, this research project has been based and inspired by a pre-research study called 'Learning Regions' (Langfeldt, 2015) as well as by studies and 
theories on context and community related school development, which are used in the presented case study.

\section{What is an inclusive School on a systemic level? Indicators and characteristics to identify and support school's potential for an inclusive development}

To be able to support a school for their development and improvement one needs first to identify the characteristics and derive indicators. In the second phase an analysis is needed to show the school's developmental potential.

The research project's objective is to improve inclusion on a systemic level (Project Description, 2016). Hereby we refer to the importance of developing the school's collective capacity for inclusion as means to develop a school, a school district and the national culture to take joint responsibility for all students' learning (Fullan, 2010). The project will focus on inclusion as a shared and joint pursuit. Therefore, we expand the concept of inclusion with the systemic level approach. To address typical characteristics of an inclusive school we make use of former empirical studies on inclusive schools (Langfeldt, 2015).

An inclusive school ...

- is strongly related to the local environment - use what is in common!

- has equal expectations towards all students with regard to their role and contribution in the school - this role definition is made explicit to the students

- has a culture of sharing (teachers share learning material, experiences, or teaching approaches)

- has a well- being perspective as well as good national test results

- has a high participation rate of students in the classroom

- makes use of a dialogic teaching approach and not a repeating or confirming one

If one has a look at school improvement Hargreaves states in 1995a that "School culture may be a cause, an object or an effect of school improvement: indeed, all three are possible. It is said that school culture should be a target for change, on the grounds that in due course it will exercise an improving causal influence on other variables, and eventually on student outcomes, which in turn reinforce the culture." (p. 41ff). If one has a closer look at a collegial school culture (Hargreaves, 1995a) one can find the following characteristics which overlap with characteristics that encourage development towards an inclusive school:

- Commitment to a shared vision for the school, providing teachers with clear purpose and direction, and so potentially strong morale.

- Coordination of policy to create a consistent environment and expectations for teachers and students.

- Methods for improving curriculum continuity and progression for students, so that unplanned repetitions or omissions are avoided, and 
teachers build on the foundations established by colleagues in related subjects or in earlier classes.

- Practices that support mutual classroom observation and discussion of teaching and learning, allowing the sharing of both problems and good practice, experimentation with new ideas, and the encouragement of reflection.

- Beside the theory mentioned, these overlapping characteristics were used to construct the survey (pre/post-test), and the workshop reflection approaches we use with the teachers. The topics included can be clustered in aspects on expectations, shared expectations and shared knowledge, school culture and the collegium itself as well as collaboration in teaching and learning.

\section{Comparing inclusive school characteristics with the Case school}

The following Table 1 shows characteristics of an inclusive school on a systemic level and a less inclusive school. We use this comparison as a working method to let teachers start reflecting on their own school culture, for instance, the underlaying relationships, and expectations.

In the left column of the Table 1, one can see the characteristic items of the Case school, based on our data analysis. On the right column one can see the characteristics of an inclusive school setting:

Table 1: Comparison of the 'Case school' results against an inclusive school

\begin{tabular}{|l|l|}
\hline $\begin{array}{l}\text { Results of our analysis on the Case } \\
\text { school }\end{array}$ & $\begin{array}{l}\text { Characteristics of an inclusive } \\
\text { school on a systemic level }\end{array}$ \\
\hline $\begin{array}{l}\text { The school is isolated from the local } \\
\text { community. }\end{array}$ & $\begin{array}{l}\text { The school is a part of the local } \\
\text { community. }\end{array}$ \\
\hline $\begin{array}{l}\text { The staff do not make use of the local } \\
\text { community and do not refer to it in } \\
\text { lessons. }\end{array}$ & $\begin{array}{l}\text { The staff make use of the local community } \\
\text { and refer to the local community in } \\
\text { lessons as well. }\end{array}$ \\
\hline $\begin{array}{l}\text { The school experiences almost no } \\
\text { support from the parents for the } \\
\text { students' learning and development. }\end{array}$ & The school is supported by the parents. \\
\hline $\begin{array}{l}\text { The staff has no joint/shared vision for } \\
\text { the development of the school. }\end{array}$ & $\begin{array}{l}\text { The staff has a shared vision for the } \\
\text { development of the school. }\end{array}$ \\
\hline $\begin{array}{l}\text { The teachers who live in the local } \\
\text { community know the students better } \\
\text { than those teachers who live abroad. }\end{array}$ & Everybody on the staff knows the pupils. \\
\hline
\end{tabular}




\begin{tabular}{|l|l|}
\hline $\begin{array}{l}\text { The staff has no shared/joint routines } \\
\text { with the students. }\end{array}$ & $\begin{array}{l}\text { The staff has shared/joint routines } \\
\text { with the students. }\end{array}$ \\
\hline $\begin{array}{l}\text { The student's socio- economic status } \\
\text { (SES) influences the expectations of the } \\
\text { staff. }\end{array}$ & $\begin{array}{l}\text { The staff has similar expectation towards } \\
\text { the students independent of their SES. }\end{array}$ \\
\hline $\begin{array}{l}\text { It is a challenge for the school and the } \\
\text { local community to address diversity. }\end{array}$ & $\begin{array}{l}\text { There is a joint responsibility to cope } \\
\text { with the diversity of students. }\end{array}$ \\
\hline
\end{tabular}

\section{School development: How to support the school staff by the inside innovation project approach?}

Hargreaves's approach to collegial school cultures has shown that the development of a school is affected by its context. Instead of primarily stressing activities based on school results and on specific and just individual provisions for inclusion, the project research focus is on the expectations in and outside the school, and the attitudes and processes which might have induced them. One central assumption is that conscious reflection on expectations (called: inside innovation) will help improve inclusion on a systemic level. Even if we know that the expectation structure is controlled by both the school and the environment one agent must start the process. The inside innovation approach focuses on the school's personnel. This is the school's staff supported by the leadership. Habermas would argue that it is the school's mandate to build and contribute to a society, in this case the local community. Education and formation are genuine prerequisites for developing a democratic developing society (Karlsen, 2011; Habermas, 1981).

As mentioned before, the inside innovation activities can be briefly described as workshops conducted on the Case schools using methods encouraging reflection such as focus groups, world café (Brown \& Issacs, 1995), mapping techniques, wall- mounted paperwork and the like. These approaches intend to increase teachers' awareness of their own assumptions regarding and expectations of their school, their teaching, the local environment as well and most central expectations about their students. To summarize the inside innovation approach of the research project: It aims to rework the expectations and attitudes teachers have to the local community, their own school culture and finally their students.

\section{Project - Survey results}

Structure of expectations, school cultures and the local community. The project conducts research on a whole school district in Norway which includes 14 comprehensive schools where as seven are innovation schools and seven are control schools. This paper reports on one of the schools as a case we characterize as 'how to overcome a local community limiting school development.' Currently we are conducting up to six workshops where the first and the last one is for data collection as a pre-/posttest approach. The remaining 
four 'innovation workshops' are conducted with the school's staff in a half school year period to support school improvement. We call this approach inside innovation because the staff choose their improvement areas on their own. The personal choose their preferred core topics for school development by using stickers to teachers' jointly selected topic of school development. This choice is based on the analysis, that is we presented the results, for instance from the survey. These results of the analysis were discussed with the teachers before, visualized and reflected by mapping techniques, focus groups talks, teachers' surveys results (see Figure 2; 3), and interviews results with pupils.

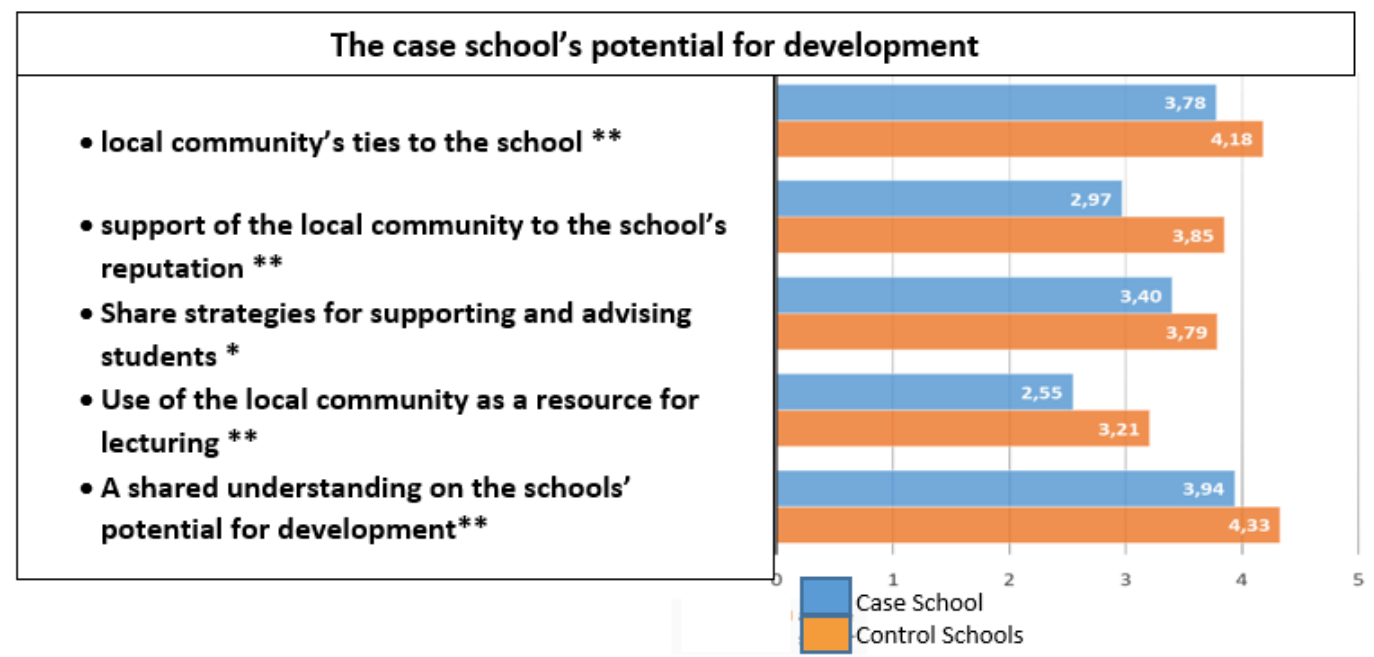

Figure 2: The Case school's potential for development

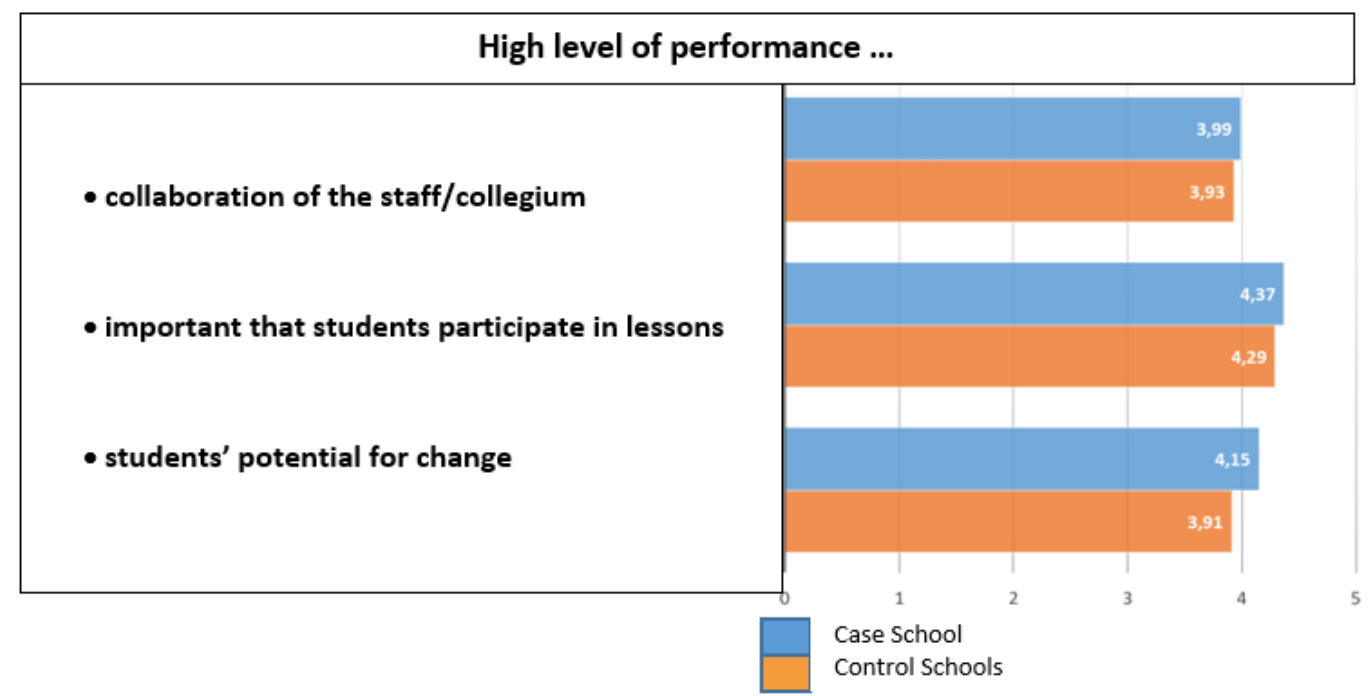

Figure 3: The Case school's high-performance areas

The survey results (Figure 2) showed the areas where school development is needed and also where the school shows a satisfying picture (Figure 3) when it comes to its inclusive and collaborative culture (Table 1). 
Having conducted the survey data collection, the Case school results were compared with the school results - that is, the average- score of four of the projects schools - using a t- test. The test results based on the survey showed items too, where the Case school achieved higher scores (Figure 2). The differences mentioned here that are significant are marked with ${ }^{* *} p<=0,05$ and * $\mathrm{p}<=0.01$.

\section{Methodological approach for theory building and use: Dynamic stories on simulation models}

Step 1. Fictitious scenarios to create insight in balancing expectation and school development. As mentioned by Goodson (2001, p. 45), "to know how the internal, external and personal will interlink, existing change theory remains underdeveloped and of progressively less use", we make use of an analytical tool, simulations models, to receive a fully conceptualized notion.

To be able to understand the systemic behavior in school development we create running simulation models. These are illustrated by fictious dynamic stories which try to explain the model's behavior (Hillen \& Gonzalez, 2010). Even if these two stories are fictious, these stories are based on the theory, and first empirical results on balancing expectations presented above. The model below (Figure 4) reveals the typical behavior of adjusting expectations (balancing loop) after a time period.

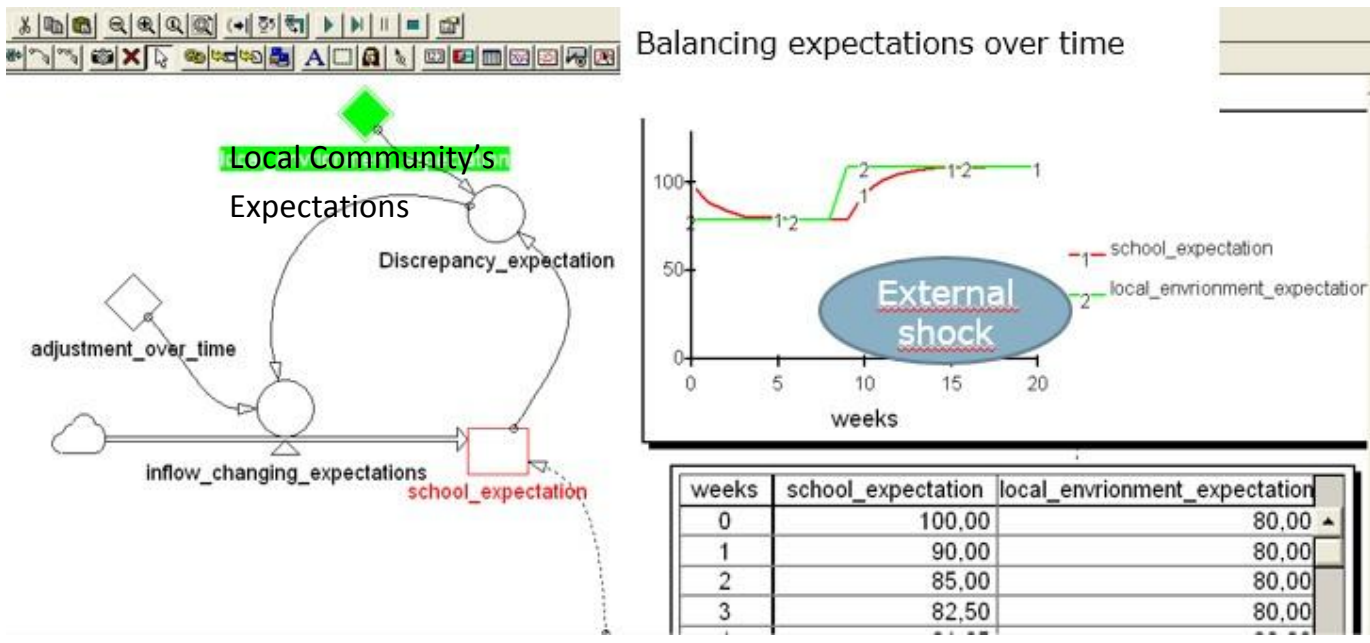

Figure 4: Simplified and aggregated SD model showing balancing of expectations through incidental shocks

Dynamic story 1 ( $t=$ week 0 - week 7): A new school year has started, and a couple of new teachers have joint the school with high expectations. By week 5 these new teachers have adjusted to expectations by experiencing the local environment, for instance by unsatisfactory work with parents or low feedback of the local environment and the existing school culture itself.

Dynamic story 2: In week 8 a new head of school has taken over. His reputation is quite high in the local environment. He was once popular because of he was the former mayor of the rural town. After a while the expectations inside school transmitted by the local environment expectations increases too. 


\section{Step 2: A model on the Case school}

Model description. The model 7a (see Figure 5) is based on the data results collected by the project on the Case school and the local community (Teacher pre-/ post-survey, student survey, focus group interviews). As mentioned in the former section we found five significant developmental areas at the Case school, as compared with the control schools:

(a) fewer ties between the school and the community,

(b) less support from the local community for the school's reputation,

(c) fewer shared strategies for supporting and advising students,

(d) less use of the local community as a resource for lecturing, and

(e) less shared understanding of the school's potential for development.

These relationships and related variables are used for the Case school model construction (see Figure 5).

Model structure of the Case school. As a main aspect in this specific SD- model (see Figure 5) on the Case school, information flows (in red) are added between the local community and the Case school as well as variables representing the school culture, representing the less developed area (e).

Because the school staff has now defined their shared goals, has started provisions and has laid down sustainable goals across and within the whole school, the SD- model 7a was added the variable 'collegial school culture' (Hargreaves, $1995 \mathrm{a}, \mathrm{b}$ ) which is the base layer for a shared vision on the school's and students' development. Specifically, information flows are added between the local community part of the model (blue) by connecting the variables: parents, local people and local organizations with the school expectation part of the model (green).

This represents the data analysis mentioned above (a- d), the developmental areas of the Case school. The variables have been constructed with time- step functions according to the activities the school has started in week 8 and 12 (see model behavior, Figure 6). As seen in the data analysis before there is a strong collaboration between the teachers but a fairly weak shared vision and joint strategy (e).

Model behavior description of the Case school. The model's simulation time is oriented on a half school year which is approximately 6- month (24 weeks). The model includes holidays because activities in the local community happen on weekends and holidays as well. One can say that in the original situation of the Case school (to), the school's high expectations of itself hasn't arrived in the local community (week 0-4). Even worse and as described in the dynamic story 1 as a scenario, the expectation has been lowered. There are no ties yet to communicate the school's high expectations.

Actually, in week 8, the Case school has started a campaign to better its reputation relative to parents and the local community, a campaign that addresses (a), (b), and (c) mentioned above. The staff conducted a 'world café' (which is a democratic tool for local community's participation) in week 9 and invited all parents and relatives to participate. 
One intention was to better meet the expectations of the parents and by this to increase the school's reputation. The staff of the Case school has chosen to work on it as a preferred topic. As mentioned before, one main concern of the school's staff is its low reputation (Table 1).

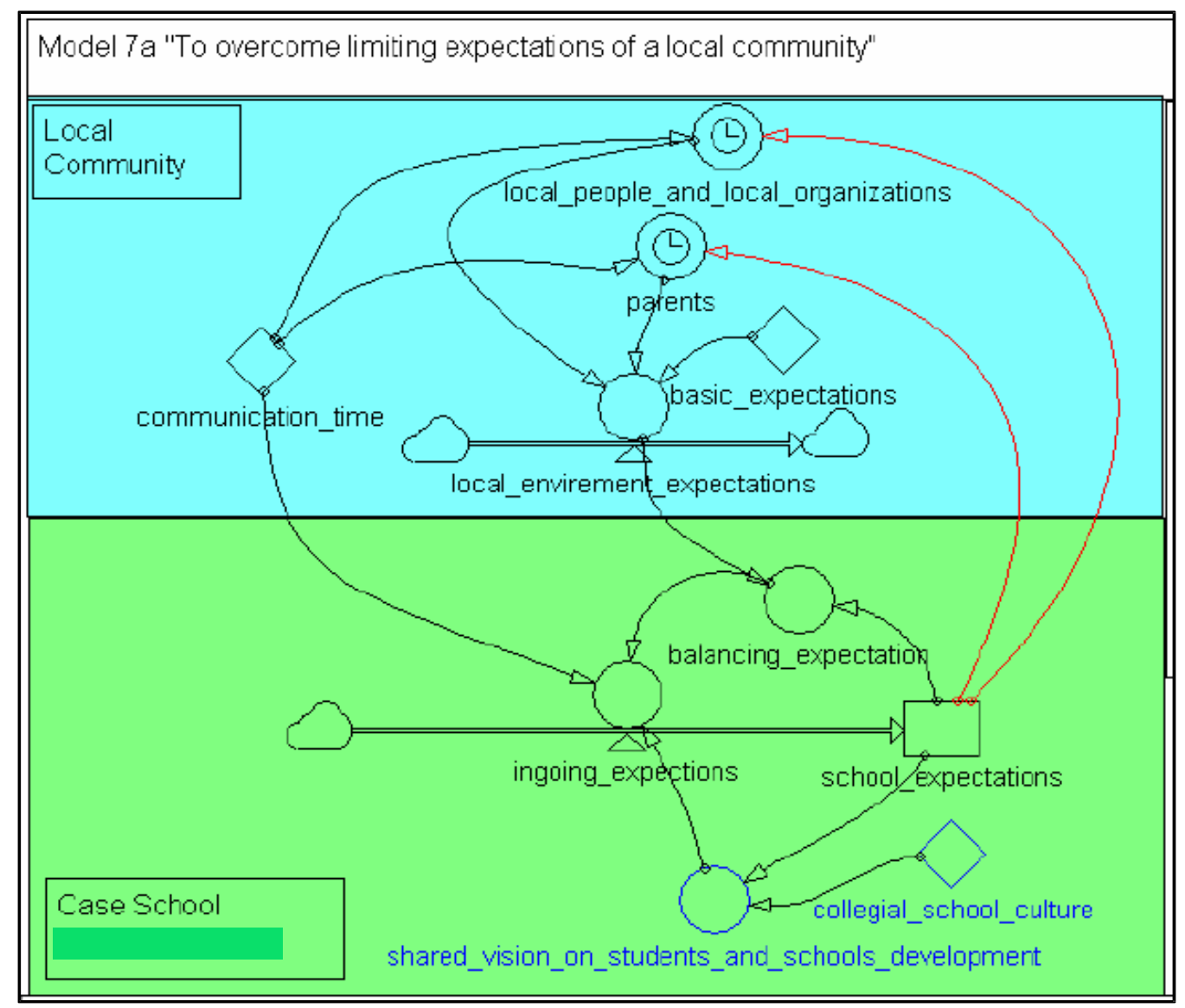

Figure 5: The Case school and its expectations structure

In addition, from the week 12 on they have started to use pensioners and other volunteers with good knowledge of the local environment and history, and as well organizations (social health organizations) of the local environment to participate and support school activities. This addresses (a) the change of weak ties between the school and the local community.

Simulation results for $\mathbf{t} \mathbf{0}$ and $\mathbf{t} \mathbf{1}$. The simulation starts with the given situation when we first went to the school to collect data (t0). We experienced that the teachers had high expectations regarding their work and teaching but lowered these over time because of the missing ties and feedback to the local school community. The staff had a collaborative culture but did not work across the school and on shared goals (week 0- 7). Working on their expectations, reflecting on their situation, sharing their intentions and objectives, the staffs began to work 'collegial' together, that is, working across the whole school and on making better connections to the local community (see Figure 6).

Week 9 (t1) the school invited parents and relatives to include the local community for participating in the schools' live world (Habermas, 1981). 
Beyond this, the staff have institutionalized working in a goal- oriented way across the school.

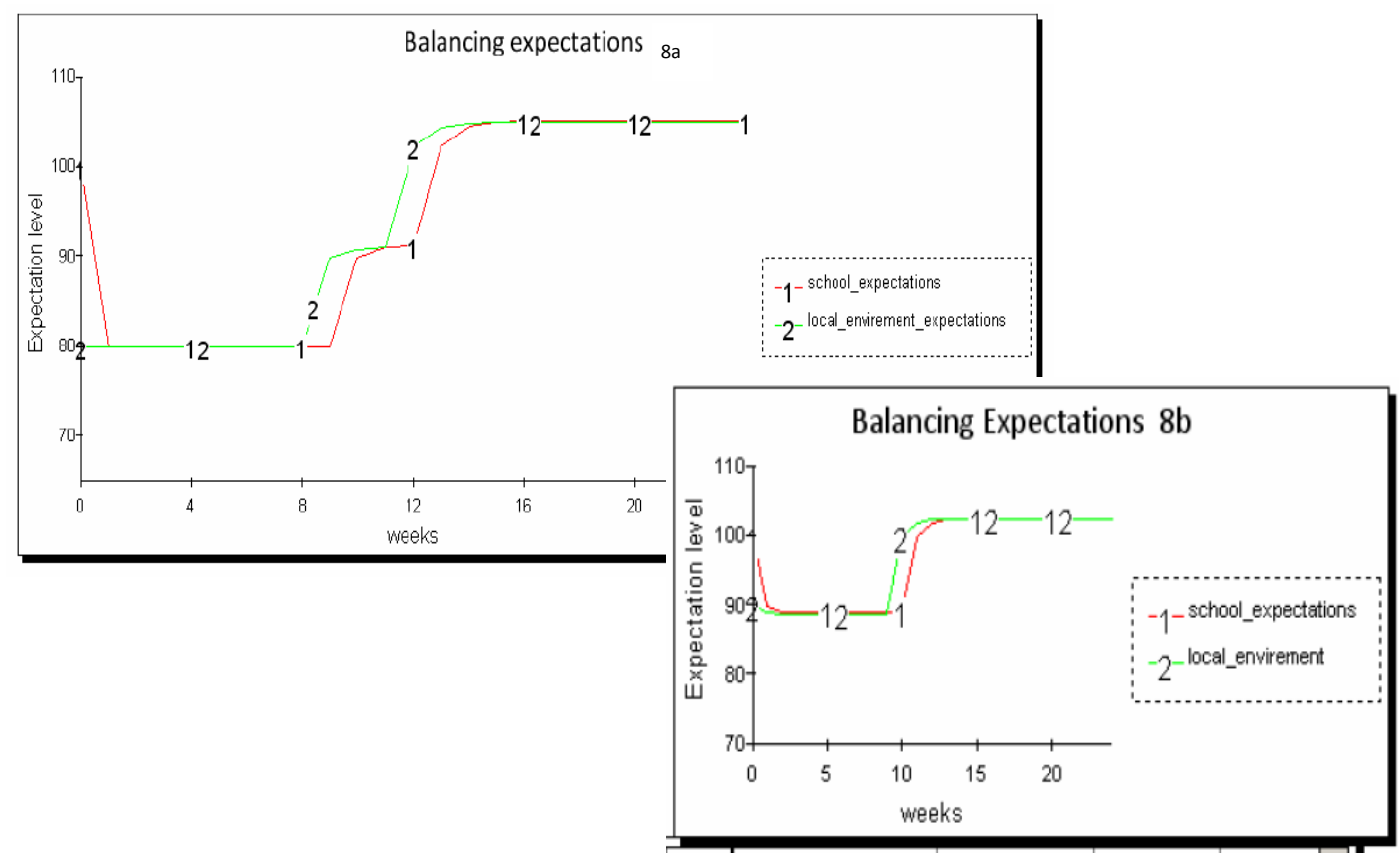

Figure 6: Simulation results on balancing expectations with and without step- function

Including knowledgeable individuals and organizations in all- day school activities is finally bringing the school culture closer to the local environment (week 10-15). The final behavior of the model is based on the school's and local community's expectation structure.

\section{Conclusion on the Case school, models' limitations, outlook and implications}

Conclusions. Looking on the behavior of the model one needs to conclude that even if the school's staff of the 'Case school' has taken over the initiative to increase the joint expectation level - they are lacking behind the local environment expectations before they are able to adjust to the local community's expectation level. One explanation is that communication time is needed before the local community, which is for instance represented by parents will have shown their willingness to support the school e.g. participate in student's development talks etc. The school's staff need to have explicitly experienced the local communities' increased expectations before adjusting to this level.

Model's limitation and outlook. In the Case school model one can criticize the use of step functions in model 7a (see Figure 5), one can see in the alternative model simulation results $8 \mathrm{~b}$ (see Figure 6 ) the same behavioral tendency, that is, the local environment as a precursor of increased higher expectations. This variation was done because one can interpret the 'inclusion of knowledgeable individuals and organizations in all- day school activities' as a smooth developmental process and not as provisions initialized at once by the school. 
However, this stresses the school initial responsibility mirrored in one of the statements by Habermas: It is the school's mandate to build and contribute to a society, in this case the local community. If one refers to Langfeldt's quote (Langfeldt, 2015) that the school's quality is created locally then the loop closes.

Finally, there is a need to model the variable 'collegial school culture' more expressively, add a variable on school reputation or even create a sub-model. We will add the data collected from the control schools too and apply another $t$ test to strengthen the underlying assumptions of the model and hence the simulation results if they are statistically significant.

Implications. The implications for research and change related to school development is multifaceted. School development research needs to continue to focus even stronger on the individual school's context as already done. Even if current studies in the field of school development and school effectiveness have been taken a variety of variables and factors into account e.g. socio-economic factors as income or social capital of the pupils' families, the school's and the community's resources etc., it seems still not comprehensive enough. In specific, it is not (just) the magnitude and the interrelatedness of the variables, in- and outside of the school, it is the inherent dynamics which is neglected. The potential levers should be addressed, particularly, the meaning of 'locality'. It encompasses a variety of subjects, organizations, and interrelations which do have a mutual impact over time as well. In addition, if conducting research on inclusion one needs to broaden the view on the concept and its actual use (Göransson \& Nilholm, 2014) which implies different 'levels' of inclusion in- and outside of the school. Finally, to stress 'inside'- school development, that is, out of the staff's formulated needs and interests, detected by their own (methodically supported) reflections, will presumably ease and enhance collegial collaboration, and motivation to accomplish the goals chosen by school's staff themselves.

\section{Acknowledgements}

Many thanks to the innovation and control schools, the research team, Jorunn $\mathrm{H}$. Midtsundstad (School-In Project leader), Inger Marie Dalehefte (Head of Department of Education at University of Agder), Kirsten J. Horrigmo (University of Agder), Grethe Ingebrigtsvold Sæbø (University of Agder), and all participants who helped to conduct the study and the data collection. Many thanks to the municipalities of the school districts, which have enabled access to the local schools and have supported the collaboration with the 14 schools in the project. We thank the Norwegian Research Council (NFR) for supporting our research project.

\section{References}

Braun, A., Ball, S. J., Maguire, M., \& Hoskins, K. (2011). Taking context seriously: towards explaining policy enactments in the secondary school. Discourse: Studies in the Cultural Politics of Education, 32(4), 585-596. https://doi.org/10.1080/01596306.2011.601555

Brown, J., \& Issacs, D. (1995). The World Café. Shaping Our Futures Through Conversations That Matter. San Francisco: McGraw- Hill Professional. 
Dale, E. L. (2008). Fellesskolen: skolefaglig læring for alle. Oslo: Cappelen akademisk. [In Norwegian: One school for all]

Fullan, M. (2010). All Systems Go. The Change Imperative for Whole System Reform. Corwin \& OPC. https:// doi.org/10.4135/9781452219554

Goodson, I. (2001). Social Histories of Educational Change. Journal of Educational Change, 2, 45- 63. https://doi.org/10.1023/a:1011508128957

Göransson, K., \& Nilholm, C. (2014). Conceptual diversities and empirical shortcomings - a critical analysis of research on inclusive education. European Journal of Special Needs Education, 29(3), 265- 280. https://doi.org/10.1080/08856257.2014.933545

Habermas, J. (1981). Theorie des kommunikativen Handelns. Suhrkamp. [In German: The Theory of Communicative Action]

Hargreaves, D. H. (1995a). School Culture, School Effectiveness and School Improvement, School Effectiveness and School Improvement, 6(1), 23- 46. https://doi.org/10.1080/0924345950060102

Hargreaves, D. H. (1995b). Beyond Collaboration: Critical Teacher Development in the Postmodern Age. In Smyth, J. (Ed.), Critical Teacher Development (pp. 149- 180.) London: Cassell, Buffalo: SUNY Press.

Hargreaves, D. H. (2014). A self- improving school system and its potential for reducing inequality. Oxford Review of Education, 40, 696- 714. https:// doi.org/10.1080/03054985.2014.979014

Hillen, S. A., \& Gonzalez, J. J. (2010). Deriving and Designing Dynamic Stories to Communicate and Learn about Information Security. In D. H. Andrews, T. D. Hull, \& K. DeMeester (Eds.), Storytelling as an instructional method: Research Perspectives (pp. 137- 152). Rotterdam: Sense Publishers.

https://www.sensepublishers.com/media/983-storytelling-as-an-instructionalmethod.pdf

Karlsen, G. E. (2011). Utdanningspolitikk, styring og marked. Universitetsforlaget. 2nd ed., Oslo. [In Norwegian: Educational Policy, Control and Marked]

Langfeldt, G. (2015). Skolens kvalitet skapes lokalt. Presententasjon av funn fra forskningsprosjektet «Larende Regioner». Fagbokforlaget, Bergen. [In Norwegian: The Quality at School is created locally]

LK06. (n.d.). Læreplanverket for Kunnskapsløftet 2006. Directory of Education. Norway. [The National Curriculum for Knowledge Promotion 2006] https:// www.udir.no/laring-og-trivsel/lareplanverket/hvordan-erlareplanene-bygd-opp/

McLaughlin, M.W., \& Talbert, J. E. (1993). Contexts That Matter for Teaching and Learning: Strategic Opportunities for Meeting the Nation's Educational Goals. Center for Research on the Context of Secondary School Teaching. Office of Educational Research and Improvement (ED), Washington. DC.

NFR (n.d.) Norwegian Research Council. https://www.forskningsradet.no/en/Home_page/1177315753906

Nilholm, C., \& Göransson, K. (2013). Inkluderende undervisning. Specialpedagogiska skolemyndigheten. [In Swedish: Inclusive teaching] https://www.kvutis.se/wp-content/uploads/2014/05/00458_tillganglig.pdf

Peterson, E.R., Rubie- Davies, C., Osborne, D., \& Sibley, C. (2016). Teachers' explicit expectations and implicit prejudiced attitudes to educational achievement: Relations with student achievement and the ethnic achievement gap. Learning and Instruction, 42, 123- 140. https:// doi.org/10.1016/j.learninstruc.2016.01.010

PISA (Programme for International Student Assessment). https://nces.ed.gov/surveys/pisa/ 
Pritchard, R. J., Morrow, D., \& Marshall, J.C. (2007). School and District Culture as Reflected in Student Voices and Student Achievement. School Effectiveness and School Improvement, 16, 153- 177. https://doi.org/10.1080/09243450500101196

Project Description. (2016). Research application. Innovasjon [In Norwegian: Innovation].

https://www.forskningsradet.no/prosjektbanken/\#/project/NFR/260539/Spr ak=en

Rist, R. (1970). Student Social Class and Teacher Expectations: The Self- Fulfilling Prophecy in Ghetto Education. Harvard Educational Review. 40(3), 411- 451. https:/ / doi.org/10.17763/haer.40.3.h0m026p670k618q3

Rosenthal, R., \& Jacobson, L. (1992). Pygmalion in the classroom: Teacher expectation and pupils' intellectual development (expanded ed.). New York: Irvington.

Skallerud, K. (2011). School reputation and its relation to parents' satisfaction and loyalty, International Journal of Educational Management, Vol. 25 Issue: 7, pp.671- 686, https://doi.org/10.1108/09513541111172081

Senge, P. M. (1990). The Fifth Discipline. New York: Klett Cotta.

Shah, M. (2012). The importance and benefits of teacher collegiality in schools -a literature review. Social and Behavioral Sciences, 46, 1242 - 1246. https://doi.org/10.1016/j.sbspro.2012.05.282

Sterman, J. D. (2000). System Thinking and Modeling for a complex world. Business Dynamics. Mc Graw- Hill.

White paper no 28, Norwegian Goverment: St.meld. nr. 28. (1998- 1999). Mot rikare mål: om einskapsskolen, det likeverdige opplæringstilbodet og ein nasjonal strategi for vurdering og kvalitetsutvikling i grunnskolen og den vidaregåande opplæringa. [In Norwegian: one school for all to enable equality in teaching] https://www.regjeringen.no/no/dokumenter/stmeld-nr-28-1999/id192278/sec1 